\title{
Determination of 8-hydroxy-2'deoxyguanosine, malondialdehyde levels and antioxidant enzyme activities in Kangal dogs with venereal tumour
}

\author{
Nazlı ERCAN ${ }^{1, a, ~} \bowtie$, Murat YÜKSEL ${ }^{2, b}$, Mustafa KOÇKAYA ${ }^{3, c}$ \\ ${ }^{1}$ Sivas Cumhuriyet University, Faculty of Veterinary Medicine, Department of Biochemistry, Sivas; ${ }^{2}$ Hatay Mustafa Kemal \\ University, Faculty of Veterinary Medicine, Department of Obstetrics and Gynecology, Hatay, ${ }^{3}$ Sivas Cumhuriyet University, Faculty \\ of Veterinary Medicine, Department of Physiology, Sivas, Turkey. \\ aORCID: 0000-0003-3542-3743; ' $\mathrm{b}$ ORCID: 0000-0001-6634-0559; ' ORCID: 0000-0001-5173-0853.
}

${ }^{凶}$ Corresponding author: nazliercan@yahoo.com

Received date: 05.12.2018- Accepted date: 12.11.2019

\begin{abstract}
Canine transmissible venereal tumour (TVT) is a contagious cancer and sexually transmitted one dog to another by allogenic transfer of living cancer cells. The aim of this study is to examine the relationship between antioxidative metabolism and venereal tumour at Kangal Dogs and to show the size of oxidative damage it causes through 8-hydroxy-2'deoxyguanosine (8OHdG). The materials of this study included the blood sera of 15 Kangal Dogs with TVT, and as a control group of 15 healthy Kangal Dogs. The sera levels of 8-OHdG were determined by competitive enzyme linked immunosorbent assay (ELISA) method. The level of malondialdehyde (MDA), superoxide dismutase (SOD), glutathione peroxidase (GPx) and catalase (CAT) which are antioxidative enzymes were investigated by spectrophotometric methods as described. Serum 8-OHdG and MDA levels of dogs with TVT were found to be significantly increased compared to the control group $(\mathrm{P}<0.001)$. The levels of GPx were statistically different $(\mathrm{P}<0.05)$. In the light of the findings, which are obtained in this study, the transmissible venereal tumour, which is an infectious and treatable type of cancer, can lead to new studies that may be caused by oxidant-antioxidant metabolism.
\end{abstract}

Keywords: Antioxidant enzyme, Kangal dog, transmissible venereal tumour, 8-OHdG.

\section{Venereal tümörlü Kangal köpeklerinde 8-hidroksi-2'deoksiguanozin, malondialdehit düzeyleri ile antioksidan enzim aktivitelerinin belirlenmesi}

Özet: Transmissible (bulaşıcı) venereal tümör (TVT), canlı kanser hücrelerinin allojenik transferiyle bir köpekten diğer bir köpeğe çiftleşme ile bulaşan bir kanser türüdür. Bu çalışmada, Kangal köpeklerinde önemli bir bulaşıcı kanser türü olan venereal tümör ile antioksidatif metabolizmanın arasındaki ilişkinin incelenmesi ve oksidatif hasarın boyutunun 8-hidroksi-2'deoksiguanozin (8$\mathrm{OHdG}$ ) düzeyleri üzerinden gösterilmesi amaçlandı. Bu amaçla, 15 adet TVT’li, kontrol grubu olarak 15 adet sağlıklı Kangal köpeklerinden alınan toplam 30 adet kan serumu çalışmanın materyalini oluşturdu. Bu hayvanlara ait kan serumlarında 8-OHdG kompetitif enzim bağımlı immunosorbent analiz (ELISA) yöntemi ile belirlendi. Malondialdehit (MDA), antioksidan enzimler olan süperoksit dismutaz (SOD), glutatyon peroksidaz (GPx) ve katalaz (CAT) seviyeleri ise spektrofotometrik yöntemlerle analiz edildi. TVT teşhisli köpeklerin serum 8-OHdG ve MDA düzeyleri kontrol grubundaki köpeklere göre istatiksel olarak anlamlı derecede artış gösterdiği tespit edildi $(\mathrm{P}<0,001)$. Antioksidan enzim olan $\mathrm{GPx}$ düzeylerinde istatiksel farklılık tespit edilmiştir $(\mathrm{P}<0,05)$. Bu çalışmada elde edilen sonuçlar neticesinde bulaşıcı ve tedavi edilebilir bir kanser türü olma niteliğindeki köpek bulaşıcı venereal tümörün oksidan antioksidan metabolizma kaynaklı yapılacak yeni çalışmalara yön gösterebilecek niteliktedir.

Anahtar sözcükler: Antioksidan enzim, bulaşıcı venereal tümör, Kangal köpeği, 8-OHdG.

\section{Introduction}

Transmissible venereal tumour (TVT) is a contagious tumour that affects female and male dogs by mating. The tumour is transmitted effectively by contact of mucosa. The surface membranes enable to the transmission because of disruption of mucosal integrity, abrasions or ruptures. In addition to genital contact, extragenital TVT cases can also be seen such as skin, face, nasal cavity, oral cavity, rectum and perineum are transmitted by social behavior (eg, sniffing and licking). The metastasis rate is $5 \%$ and usually occurs in regional lymph nodes $(3,18,27)$.

The fact that contagious venereal tumour is a cancer type which can be transmitted easily from one dog to 
another by the allogenic transfer of live cancer cells that increase the importance of this disease (22). While deaths can usually be seen in cancer patients, it should not be ignored that in many of the TVT cases can gain of lifetime immunity and this may contribute to cancer studies by revealing the mechanism (29).

The increase in the cancer incidence can be due to the increased DNA damage or reduced repair mechanism. The oxidative damage occurs because of altered DNA's. The DNA damage products are resulting in endogenously formed by oxygen radicals. These products are known to cause degenerative diseases such as aging, cancer and heart disease (7). Many studies that aim to research the markers for early diagnosis of a disease with poor prognosis such as cancer have focused on free radicals and oxidative stress especially in recent years (8). Endogenic formation of reactive oxygen species (ROS) leads to oxidation of DNA. Beside the factors that cause cancer, the cancer formation mechanism includes the DNA damage formed by ROS (17). 8-hydroxy-2'deoxyguanosine (8-OHdG) which is one of the DNA damage products of reactive oxygen species, is a commonly used marker in determining the extent of the DNA damage (31). Although there are over more than 20 oxidative damage products, due to its potential for susceptibility and mutagenicity are focused on most and have been the subject of many studies that 8hydroxyguanine or its deoxynucleotide $8-\mathrm{OHdG}(6,14$, $16,20,28,29$ ).

Oxygen radicals, usually products of metabolism in vivo are also formed by phagocyte cells and lipid peroxidation (7). The measurement markers of lipid peroxidation are pentane, malondialdehyde (MDA), lipid hydroperoxides and isoprost (26). MDA which is a lipid peroxidation product is known as an important and most commonly used marker in evaluating oxidative stress (25). The free radicals that form the oxidative damage are defused by catalase (CAT), superoxide dismutase (SOD), glutathione peroxidase (GPx) and nonenzymatic antioxidants which are enzymes of defense system (26).

TVT is an important cancer type of cancer among cancer types because of a kind of cancer that is transmitted by mating of dogs from one to another by means of allogenic transfer of living cancer cells and also it shows fast endemic spread and resulting in restraints dogs for breeding. At the same time, it can that by enlightening the mechanism of a cancer with this etiology can contribute to studies conveyed on other types of cancer. Therefore, this study aims to examine the relationship between venereal tumour cases that are clinically significant and known as contagious cancer and antioxidative metabolism on Kangal Dogs peculiar to Sivas province which are grown in public farms and raised by people and to show the extent of oxidative damage via $8-\mathrm{OHdG}$.

\section{Material and Methods}

This study was approved by the Sivas Cumhuriyet University Animal Research Ethics Committee dated 23.02.2016 and numbered 23. The materials of this study included the blood sera of 15 dogs with TVT which are cytological (Figure 1) and clinically examined, and of 15 healthy dogs, all in Kangal breeding farm and people in Sivas.

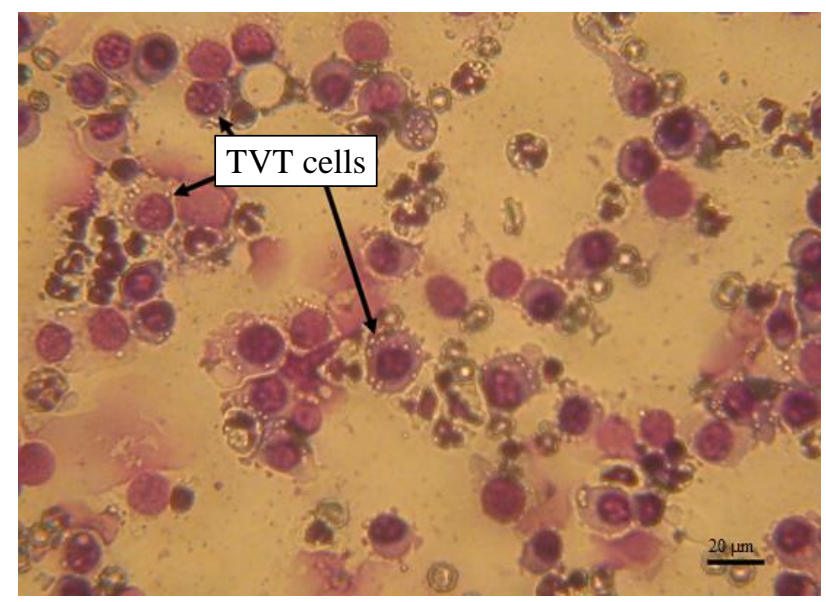

Figure 1. TVT cell via cytological.

Giemsa staining technique microscopy magnification 400x, scale bar: $20 \mu \mathrm{m}$.

Blood for biochemical analysis was taken from each dog by vena cephalica antebrachii into biochemistry tubes, brought to the Sivas Cumhuriyet University Faculty of Veterinary Medicine Department of Biochemistry lab and centrifuged at 4,000 rpm for $10 \mathrm{~min}$. Sera were stored at $-20{ }^{\circ} \mathrm{C}$ until the day of analysis.

The serum levels of $8-\mathrm{OHdG}$ were determined by competitive ELISA (enzyme linked immunosorbent assay) method. Analyzes were performed with the ELISA device (Thermo Scientific, Multiskan Go, USA), according to the kit procedures using SUNRED Canine 8OHdG (Cat. No. DZE201151217) assay.

According to test procedure, added to microplate wells from $50 \mu \mathrm{l}$ each standard $(4,8,16,32,64 \mathrm{ng} / \mathrm{ml})$ and $50 \mu 1$ streptavidin-HRP included in the kit. And $40 \mu 1$ of each sample was transferred to micro wells and $10 \mu 1$ of 8 OHdG antibody and $50 \mu \mathrm{l}$ of streptavidin-HRP were added. The microplate was covered and incubated for 1 hour at $37^{\circ} \mathrm{C}$ in a dark environment. At the end of the incubation, the wells were washed 3 times with wash buffer. After washing, were added $50 \mu \mathrm{l}$ of chromogen solution A and $50 \mu \mathrm{l}$ of chromogen solution B to each well and incubated for $10 \mathrm{~min}$. At the end of the incubation, 50 $\mu 1$ of stop solution was added to each well to change the blue color to yellow. Finally, the absorbance of the standard and samples was measured on an ELISA device at a wavelength of $450 \mathrm{~nm}$. Calibration curve was calculated for the absorbance values obtained and the $8 \mathrm{OHdG}$ levels were calculated as $\mathrm{ng} / \mathrm{ml}$ against the absorbance of the samples. 
MDA measurement was performed according to the Janero (11) method. The principle of this method is based on measuring the absorbance of the color produced by MDA with thiobarbituric acid (TBA) in acidic medium. For this purpose, $50 \mu \mathrm{l}$ of sample was taken, $250 \mu \mathrm{l}$ of TCA and $100 \mu \mathrm{l}$ of TBA solutions were added and incubated at $95^{\circ} \mathrm{C}$ for 30 minutes. After cooling the samples, the absorbance at $535 \mathrm{~nm}$ was measured spectrophotometrically in a microtiter plate reader (Thermo Scientific, Multiskan Go, USA). Standards were prepared using 1,1,3,3, tetramethoxypropane, formed by hydrolysis of this compound. The standard graph was drawn using these results and MDA results were calculated with this graph.

Determination of SOD activity according to Sun et al. (23) and Durak et al. (5) which the superoxide produced by the xanthine / xanthine oxidase system is based on reduction of nitro blue tetrazolium (NBT). The resulting superoxide radicals $\left(\mathrm{O}_{2}\right)$ reduce NBT and form a colored formazan. This complex gives maximum absorbance at $560 \mathrm{~nm}$. When SOD is present in the medium, there is no NBT reduction and does not turn blue-violet and a light color is formed depending on the amount and activity of the enzyme. Determined in a microtiter plate reader (Thermo Scientific, Multiskan Go, USA).

Determination of GPx activity according to Paglia and Valentine (19) was determined by kinetic, spectrophotometric analysis in which the incubation mixture containing phosphate buffer solution (PBS), nicotinamide adenine dinucleotide phosphate (NADPH), glutathione disulfide (GSSG), reduced glutathione (GSH), Na-azide and ethylenediaminetetraacetic acid (EDTA) was pre-incubated for 10 minutes at $37^{\circ} \mathrm{C}$. The addition of hydrogen peroxidase and the decrease in absorbance at $340 \mathrm{~nm}$ were determined kinetically in a microtiter plate reader (Thermo Scientific, Multiskan Go, USA).

Catalase activity was calculated using the method of Aebi (1). $50 \mathrm{mM}$ phosphate buffer was prepared with $\mathrm{pH}$ 7.0; further, $30 \mathrm{mM}$ hydrogen peroxide solution was prepared. $1 \mathrm{~mL}$ of $\mathrm{H}_{2} \mathrm{O}_{2}$ was added to a $2 \mathrm{~mL}$ sample, 1 $\mathrm{mL}$ of phosphate buffer was added to the resulting solution and measurements were made at $230 \mathrm{~nm}$ in a microtiter plate reader (Thermo Scientific, Multiskan Go, USA).

The data were compared in SPSS 22.00 statistical analysis program (21). The normality of data distributions was investigated by Kolmogorov Smirnov test. Student $t$ test was used for parametric variables for the comparison of the studied parameters whether there is a statistical difference or not. Differences were considered with significant at $\mathrm{P}<0.05$.

\section{Results}

The serum levels of 8-OHdG, MDA, SOD, GPx and CAT the dogs with TVT and control group shown in Table 1. According to Table 1, it was found that serum levels of 8 -OHdG dogs $(55.46 \pm 5.02 \mathrm{ng} / \mathrm{ml})$ with TVT diagnosis were significantly increased compared to the control group $(8.78 \pm 0.70 \mathrm{ng} / \mathrm{ml})$ dogs $(\mathrm{P}<0.001)$.

The levels of MDA were found to be statistically significant increase in dogs $(3.32 \pm 0.29 \mathrm{nmol} / \mathrm{ml})$ with TVT diagnosis compared to control dogs $(1.12 \pm 0.14$ $\mathrm{nmol} / \mathrm{ml})$ as shown in Table $1(\mathrm{P}<0.001)$.

The levels of GPx were statistically significant between TVT $(0.565 \pm 0.122 \mathrm{U} / \mathrm{ml})$ and control groups $(1.512 \pm 0.362 \mathrm{U} / \mathrm{ml})(\mathrm{P}<0.05)$. The levels SOD did not show any statistical difference between TVT $(66.2 \pm 2.31$ $\mathrm{U} / \mathrm{L})$ and control groups $(71.09 \pm 1.0 \mathrm{U} / \mathrm{L})(\mathrm{P}>0.05)$. The levels CAT did not show any statistical difference between TVT $(43.43 \pm 4.13 \mathrm{U} / \mathrm{ml})$ and control groups $(48.93 \pm 8.79 \mathrm{U} / \mathrm{ml})(\mathrm{P}>0.05)$.

\section{Discussion and Conclusion}

Antioxidant defense system is in a condition of equilibrium with free radicals formed in various ways in the organism. However, in cases where free radicals cannot be cleaned adequately from the organism it damages to the DNA and damage products are formed. These damage products can lead to various metabolic diseases, such as aging, cancer and even modifications in DNA structure. The most well-known damage product is $8-\mathrm{OHdG}$ which is mutagenic (9).

Table 1. Serum 8-hydroxy-2'-deoxyguanosine (8-OHdG), malondialdeyde (MDA), superoxide dismutase (SOD), catalase (CAT) and glutathione peroxidase (GPx) levels of transmissible venereal tumour (TVT) and control groups.

\begin{tabular}{lccc}
\hline Parameters & $\begin{array}{c}\text { TVT group } \\
(\text { Mean } \pm \text { SE) }\end{array}$ & $\begin{array}{c}\text { Control group } \\
(\text { Mean } \pm \text { SE) }\end{array}$ & P \\
\hline 8-OHdG (ng/ml) & $55.46 \pm 5.02$ & $8.78 \pm 0.70$ & 0.001 \\
MDA (nmol/ml) & $3.32 \pm 0.29$ & $1.12 \pm 0.14$ & 0.001 \\
SOD (U/L) & $66.2 \pm 2.31$ & $71.09 \pm 1.0$ & 0.065 \\
CAT (U/ml) & $43.43 \pm 4.13$ & $48.93 \pm 8.79$ & 0.576 \\
GPx (U/ml) & $0.565 \pm 0.122$ & $1.512 \pm 0.362$ & 0.020 \\
\hline
\end{tabular}

Data are presented as (Mean \pm SE). SE: Standard error. Statistical comparisons were performed using Student $t$-test. Differences were considered statistically significant at $\mathrm{P}<0.05$. 
The increase of reactive species can raise the development of malignancy and can be responsible for the rise in growth of cancer risk. The ineffectiveness of various antioxidant defense system enzymes can further increase the levels of oxidative damage and increase the cancer development in animals. Particular attention should be paid on DNA oxidative damage formed by a reactive kind such as hydroxyl radical (9). In many studies in the field of humanities and veterinary medicine increased oxidative damage in cancer patients has been associated with increased cancer risk $(6,10,14,16,20,28,29,30)$.

In a study which determines the malondialdehyde, antioxidant activity and adenosine levels in serum of dogs with TVT, serum MDA levels were found significantly higher in dogs with TVT than in healthy dogs but antioxidant activities were lower. MDA levels were found as $2.347 \mathrm{nmol} / \mathrm{mL}$ in dogs with TVT and $1.512 \mathrm{nmol} / \mathrm{mL}$ in healthy dogs (2). In this study, MDA levels at TVT diagnosed $\operatorname{dogs}$ were found to be $3.32 \mathrm{nmol} / \mathrm{mL}$ and $1.12 \mathrm{nmol} / \mathrm{mL}$ at healthy dogs. The results of Aydin et al. (2) are similar to the results of this study with increased MDA levels in TVT patients.

It is claimed that oxidant-antioxidant balance is an important factor in cancer formation and progression. An 8-OHdG level that is product of DNA oxidation and SOD, GPx and glutathione $S$ transferase (GST) activities were measured as antioxidant activity in patients with bladder cancer. By means of serum 8-OHdG level and GPx activities, there were not any significant differences between the patient and control group. However, SOD activity were significantly lower and GST activity was significantly higher in the patient group (4).

In a study conducted by Macotpet et al. (15), malondialdehyde levels were evaluated in blood samples from dogs having cancer $(n=80)$ and clinically healthy $\operatorname{dogs}(n=101)$. Serum MDA was significantly higher in dogs with cancer than in clinically healthy dogs.

In another study, two control and patient groups were formed according to healthy female $\operatorname{dogs}(n=13)$ and female dogs $(n=16)$ diagnosed with pyoderma and healthy male dogs $(n=14)$ and male dogs $(n=12)$ diagnosed with. MDA were measured in plasma and 8-hydroxy2 'deoxyguanosine levels were measured in urine. MDA and $8-\mathrm{OHdG}$ levels were found to be statistically significant in male and female dogs diagnosed with pyoderma (6).

The results of high MDA and 8-OHdG levels found in TVT diagnosed dogs obtained from this study are similar to the results of Macotpet et al. (15) and Ercan and Fidanc1 (6). It leads to the conclusion that oxidative stress can be associated with cancer types in dogs.

Antioxidant levels were researched at multicentric lymphoma, oral fibrosarcoma, mast cell tumours, malignant melanoma, appendicular ostosarcoma, nasal tumours and peripheral ameloblastoma at dogs with cancer. Total antioxidant capacity (TAC), antioxidant enzymes which are GPx, CAT and SOD levels were measured. As a result, except for patients with nasal tumour, increased levels of SOD in patients with malignant melanoma, mast cell tumour, multicentric lymphoma and oral fibrosarcoma, increased levels of GPX and total antioxidant capacity in osteosarcoma and multicentric lymphoma patients, increased in levels of CAT and SOD at 42 dogs with cancer (24). In this study, it was observed that there was no increase at the levels of SOD, CAT and GPx in dogs with TVT but the levels were lower compared to the control group. The decrease, which is not reflected to the statistical difference, composes the result of increasing oxidative damage.

In a study in which lipid peroxidation and antioxidant enzyme levels were compared between dogs diagnosed with breast tumour and healthy dogs. The levels of lipid peroxidation have shown a significant increase in dogs diagnosed with breast tumour. It was determined that glutathione reductase levels showed significant increase in breast tumour patients when the antioxidant levels are evaluated (12).

Kumaraguruparan et al., (13) have observed in their study about breast tumour diagnosed dogs that increased antioxidant levels have an effect of reducing the peroxidation levels. SOD, CAT and GPx levels in dogs with tumours were found to be doubled compared to the normal tissues.

This study, in means of antioxidant enzyme levels, does not resemble to the results of studies of Jayasri et al., (12), Kumaraguruparan et al., (13). This study indicates that increased oxidative damage in TVT patients leads to a decrease in antioxidant enzyme.

In conclusion, the levels of 8-OHdG and MDA were found high in dogs with transmissible venereal tumours. Although a statistical difference was detected only at GPx levels, the significant decrease in antioxidant enzymes of SOD, GPx and CAT levels in dogs with TVT was remarkable. Increased oxidative damage and lipid peroxidation levels affect the changes in formation of antioxidant enzyme levels. In the light of the findings, which are obtained in this study, the transmissible venereal tumour, which is a contagious and treatable type of cancer, can lead to new studies that may be caused by oxidant-antioxidant metabolism. It can be concluded that the use of additional oxidative stress markers and antioxidant parameters may be useful in order to reveal the unknown activation mechanisms with more patients and more studies although activation of oxidant-antioxidant defense is observed in dogs with TVT. 


\section{Acknowledgements}

The present study was presented in Mediterranean Veterinary Congress coupled with $7^{\text {th }}$ REEV-Med General Assembly, 13-14 December, 2018, Kırıkkale, Turkey.

\section{Financial Support}

This study was supported by the Sivas Cumhuriyet University Scientific Research Project Coordination Unit under the project number ' $\mathrm{V}-042$ '.

\section{Conflict of Interest}

The authors declared that there is no conflict of interest.

\section{References}

1. Aebi H (1984): Catalase in vitro. Methods Enzymol, 105, 121-6.

2. Aydın İ, Bülbül A, Avcı GE, et al (2009): Serum oxidative status and adenosine deaminase activity in dogs with transmissible venereal tumour. Bull Vet Inst Pulawy, 53, 771-774.

3. Baştan A, Baki Acar D, Cengiz M (2008): Uterine and ovarian metastasis of transmissible venereal tumour in a bitch. Turk J Vet Anim Sci, 32, 65-66.

4. Dinçer Y, Akçay T, Kural AR, et al (2011): Evaluation of 8-hydroxy-2'-deoxyguanosine concentration and antioxidant enzyme activities in bladder cancer patients. Turkiye Klinikleri J Med Sci, 31, 553-558.

5. Durak I, Yurtaslanı Z, Canbolat O, et al (1993): A methodological approach to superoxide dismutase (SOD) activity assay based on inhibition of nitroblue tetrazolium (NBT) reduction. Clin Chim Acta, 214,103-104.

6. Ercan N, Fidancı UR (2012): Piyodermalı köpeklerde 8hidroksi-2'-deoksiguanozin (8-OHdG) düzeyleri. Ankara Üniv Vet Fak Derg, 59, 163-168.

7. Fraga C, Shigenaga M, Park J, et al (1990): Oxidative damage to DNA during aging: 8-Hydroxy-2'deoxyguanosine in rat organ DNA urine. Proc Natl Acad Sci, 87, 4533-4537.

8. Gencer M, Ceyla E, Aksoy A, et al (2005): Oksidatif stres benign ve malign akciğer hastaliklarinin ayirıcı tanısinda belirteç olabilir mi? Akciğer Arşivi, 6, 89-92.

9. Haliwell B (2007): Oxidative stress and cancer: have we moved forward? Biochem J, 401, 1-11.

10. Hattori Y, Nishigori C, Tanaka T, et al (1996): 8hydroxy-2'-deoxyguanosine is increased in epidermal cells of hairless mice after chronic ultraviolet B exposure. $\mathrm{J}$ Invest Dermatol, 107, 733-737.

11. Janero DR (1990): Malondialdehyde and thiobarbituric acid-reactivy as diagnostic indices of lipid peroxidation and peroxidative tissue injury. Free Radic Biol Med, 9, 515-540.

12. Jayasri K, Padmaja K, Saibaba M (2016): Altered oxidative stress and carbohydrate metabolism in canine mammary tumors. Veterinary world, $\mathbf{9}, 1489$.

13. Kumaraguruparan R, Balachandran C, Manohar BM, et al (2005): Altered oxidant-antioxidant profile in canine mammary tumours, Vet Res Commun, 29, 287-96.
14. Lin H, Jenner A, Ong C, et al (2004): A high-throughput and sensitive methodology for the quantification of urinary 8-hydroxy-2'-deoxyguanosine: measurement with gas chromatography-mass spectrometry after single solidphase extraction. Biochem J, 380, 541-548.

15. Macotpet A, Suksawat F, Sukon P, et al (2013): Oxidative stress in cancer-bearing dogs assessed by measuring serum malondialdehyde. BMC Vet Res, 9, 101.

16. Martinis B, Bianchi M (2002): Methodology for urinary 8hydroxy-2'-deoxyguanosine analysis by HPLC with electrochemical detection. Pharmacol Res, 46, 129-131.

17. Matsufuji H, Ochi H, Shibamoto T (2006): Formation and inhibition of genotoxic malonaldehyde from DNA oxidation controlled with EDTA. Food Chem Toxicol, 44, 236-241.

18. Nak D, Mısırlığlu D, Nak Y, et al (2004): Bir köpekte meme metastazl transmissible venereal tümör olgusu. Vet Bil Derg, 20, 99-102.

19. Paglia DE, WN Valentine (1967): Studies on the quantitative and qualitative characterization of erythrocyte glutathione peroxidase. J Lab Clin Med, 70, 158-169.

20. Pilger A, Ivancsits S, Germadnik D, et al (2002): Urinary excretion of 8-hydroxy-2'-deoxyguanosine measured by high-performance liquid chromatography with electrochemical detection. J Chromatogr B, 778, 393-401.

21. SPSS (2014): IBM SPSS Statistics for Windows, version 22.00. SPSS Inc., Chicago, IL.

22. Strakova A, Murchison EP (2014): The changing global distribution and prevalence of canine transmissible venereal tumour. BMC Vet Res, 10, 168.

23. Sun Y, Oberley LW, Li Y (1988): A simple method for clinical assay of superoxide dismutase. Clin Chem, 34, 497500.

24. Tanja P, Alenka NS, Butinar J, et al (2008): Antioxidant status in canine cancer patients. Acta Vet Beograd, 58, 275286.

25. Tüközkan N, Erdamar H, Seven I (2006): Measurement of total malondialdehyde in plasma and tissues by highperformance liquid chromatography and thiobarbituric acid assay. Firat Tip Derg, 11, 88-92.

26. Urso ML, Clarkson PM (2003): Oxidative stress, exercise and antioxidant supplementation. Toxicology, 189, 41-54.

27. Welsh JS (2011). Contagious Cancer. The Oncologist, 16, 1-4.

28. Winter JL, Barber LG., Freeman L, et al (2009): Antioxidant status and biomarkers of oxidative stress in dogs with Lymphoma. J Vet Intern Med, 23, 311-316.

29. Wiseman H, Kaur H, Halliwell B (1995): DNA damage and cancer: measurement and mechanism. Cancer Letters, 93, 113-120.

30. Wu LL, Chiou CC, Chang PY, et al (2004): Urinary 8OHdG: a marker of oxidative stress to DNA and a risk factor for cancer, atherosclerosis and diabetics Clin Chim Acta, 339, 1-9.

31. Zhang F, Stott WT, Clark AJ, et al (2007): Quantitation of 8-hydroxydeoxyguanosine in DNA by liquid chromatography/positive atmospheric pressure photoionization tandem mass spectrometry. Rapid Commun Mass Spectrom, 21, 3949-3955. 